\title{
ポストカラム高速液体クロマトグラフィーによる 点眼液中のアラントイン及びタウリンの同時定量
}

\author{
横山 俊夫 ${ }^{\circledR *}$ ，木下 俊夫**
}

(1991 年: 2 月 26 日受理)

\begin{abstract}
アラントイン及びタウリンを次曲塩素酸ナトリウムにより酸化した後, 生成した塩素化物と, チアミ ンとのチオクローム反忍によって発蛍光させるポストカラム検出法を開発し，これを用いた HPLCに

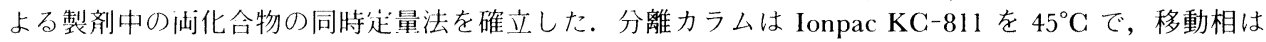
$0.1 \%$ リン酸を用いた。 カラム溶出液に次㘫塩素酸試薬を混合し反応コイル A に導入した。次にチアミ ン試薬を混合し反忍コイル B を通した後, 蛍光強度を励起波長 $370 \mathrm{~nm}$ 蛍光波長 $420 \mathrm{~nm}$ で測定した. 次州塭素酸試薬は $0.05 \%$ 有効塭素と $60 \mathrm{mM} \mathrm{NaOH}$ を含む $0.1 \mathrm{M}$ リン酸緩衝液 $(\mathrm{pH} 7.5)$ の次亜塩素 酸ナトリウム溶液，チアミン試薬は $1 \% \mathrm{NaNO}_{2}$ を含む $0.1 \mathrm{M}$ リン酸緩衝液（ $\mathrm{pH} 7.5 ）$ の $0.02 \%$ 塩酸 チアミン浴液を用いた。検量線はアラントイン，タウリンともに $20 \mathrm{ng} \sim 2 \mu \mathrm{g}$ の範囲で直線となり，添 加四収䜌は 97.9〜 101.4\% で，妨害物質もほとんどなかった。
\end{abstract}

\section{1 緒 \\ アラントイン $(\mathrm{Alt})$ ，タウリン ( Tau) はそれぞれ肉} 芽形成作湖や解毒作用を期待して種々の薬剂, 例えば点 眼液, 皮膚外扭剂や内服用液剂に多く配合されている。

今吅，製剂中の Alt と Tau の同時定量法について検討 した。

Alt の运量法に関してはアルカリ加水分解により生じ

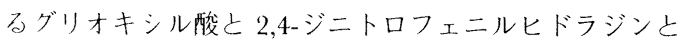

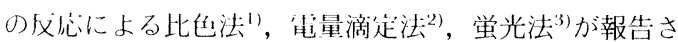
れている.しかし，これらの方法は混在物により影響さ れやすく, 繁雑な㓩処理が必要で, 又, 感度も低かっ t.

近年:発達した HPLC 法による企量法では, 一般に用 いられている ODS カラムには Alt が保持されにくいた めシリカ $\mathrm{NH}_{2}$ 力ラム゙が井いられているが，このカラ ムは寿命が短い。辻ら ${ }^{5)(6)}$ は Alt をイオン交換カラムに より分離した後, NaOClにより处理し, 生成した $N$-ク ロラミンをI-と仪忍させ $370 \mathrm{~nm}$ で測定するポストカ ラム法を報告しているが，感度が低いうえに，送液ポン

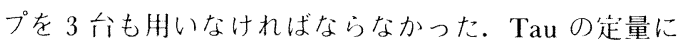
ついては, HPLC法では TauにはUV吸収がないた

* エスエス製薬中央研究所：286 干葉県成田市南平台 1143

** 北里大学薬学部：108 東京都港区自金 5-9-1
め, 主にポストカラム誘導体化法 ${ }^{78)}$ ，あるいはプレカ ラム誘導体化法 $\left.{ }^{9}\right)^{\prime}$ 用いられていた。しかし，これらの 方法はいずれもアミノ基の反忍に基づいているために妨 害物質が多く，誘導体化のための前処理に多大な時間を 必要とした。

最近，著者らは，タンパク質中のペプチド結合を

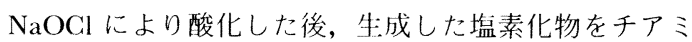
ンと反心させ，強い蛍光を持つチオクロームの生成をポ ストカラムに利用した HPLCによるタンパク質の蛍光 定量法を報告 ${ }^{10)}$ した。

更にこの反応が Tau にも起こることから生体試料中 の Tauの定量にも忘用した ${ }^{11)}$.

本研究では, Alt 中のウレイド基に注目して, Alt に 対する本反応の応用を検討し，製剤中の Alt と Tau の ポストカラム HPLCによる同時定量法を確立した.

$$
2 \text { 実験 }
$$

\section{$2 \cdot 1$ 試 薬}

標準品の Alt, Tauはそれぞれ, 川研ファインケミカ ル製，岩城製薬製を，内部標準物質の 5,5-ジメチルヒダ ントイン (DMH) は東京化成工業製試薬一級を，その 他の試薬は和光純薬工業製特級を用いた。

$\mathrm{NaOCl}$ 試薬はアンチフォルミン ${ }^{\circledR} 5 \mathrm{ml}$ に $1 \mathrm{M} \mathrm{NaOH}$ $60 \mathrm{ml}$ を加えた後, $\mathrm{pH} 7.5$ の $0.1 \mathrm{M}$ リン酸緩衝液を加 えて $1000 \mathrm{ml}$ とした。この液の有効塩素最終濃度は 
$0.05 \%$ で, $\mathrm{pH}$ は 11.5 である.

チアミン試薬は $\mathrm{NaNO}_{2} 10 \mathrm{~g}$ と塩酸チアミン $0.2 \mathrm{~g}$ を $0.1 \mathrm{M} \mathrm{NaH}_{2} \mathrm{PO}_{4}$ 溶液に溶解後 $0.1 \mathrm{M} \mathrm{Na}_{2} \mathrm{HPO}_{4}$ 溶液を 加えて $\mathrm{pH} 7.5$ に調整した後, $\mathrm{pH} 7.5$ の $0.1 \mathrm{M}$ リン酸 緩衝液を加えて $1000 \mathrm{ml}$ とした.

両試薬とも Brij 35 を $0.1 \%$ 添加した.

\section{$2 \cdot 2$ 装置及び分析条件}

分離力ラムは Shodex Ionpac KG-811 (25 cm ×6.0 $\mathrm{mm})$ を $45^{\circ} \mathrm{C}$ で使用し, 移動相は $0.1 \%$ リン酸を島津 製作所製 LC-6A 型ポンプを用いて, $0.8 \mathrm{ml} / \mathrm{min}$ で送液 した。ポストカラム反応は, まず溶出液に対して次亜塩 素酸試薬を同型ポンプを用い $0.3 \mathrm{ml} / \mathrm{min}$ で送液し混合 した後, 室温水浴中のコイル A $(3 \mathrm{~m} \times 0.5 \mathrm{~mm}$ PTFE 製）に導入した. 次いでチアミン試薬を同様の送液条件 で混合し $60^{\circ} \mathrm{C}$ の恒温槽（大洋サービスセンター製サー モマインダー $\mathrm{Jr}-80$ 型) 中のコイル B $(5 \mathrm{~m} \times 0.5 \mathrm{~mm}$ PTFE 製) に導いた。 その後, 冷却コイル $(1 \mathrm{~m} \times 0.5$ mm PTFE 製) を通した後, 蛍光強度を励起波長 370 $\mathrm{nm}$, 蛍光波長 $420 \mathrm{~nm}$ で島津製作所製 RF-535 型営光 検出器により測定した。必要に応じて UV 検出器（島 津製作所製 SPD-6A 型) を分析カラムとポストカラム 反忍系の間に接続した。

\section{$2 \cdot 3$ 定量操作}

Alt と Tau を各々 $0.1 \%$ 含有する点眼液を標準試料 として, 又, 市販されている点眼液を試料として用い た. Alt 又は Tau $1 \mathrm{mg}$ 相当量の検体 $1 \mathrm{ml}$ をホールピ

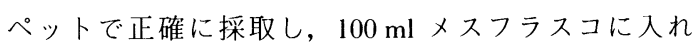
た。これに内標準溶液である DMH の $200 \mu \mathrm{g} / \mathrm{ml}$ 溶液 $10 \mathrm{ml}$ をホールピペットで正確に加えた後, 水で $100 \mathrm{ml}$ とした。協和精密製 KMT-60AGII 型オートサンプ ラーを用いて $20 \mu \mathrm{l}$ を HPLC に注入した.

\section{3 結果及び考察}

\section{$3 \cdot 1$ ポストカラム条件の検討}

蛍光反応条件は, FIA により Alt, Tau の $10 \mu \mathrm{g} / \mathrm{ml}$ 水溶液を用いて検討した。試薬流量, 反応コイル長さは 既報 ${ }^{1)}$ に準じた。 $\mathrm{NaOGI}$ 試薬中の有効塩素濃度と蛍光 強度の関係を Fig. 1 に示す. Alt は有効塩素濃度 $0.05 \%$ のとき, 最高の蛍光強度を示し, Tauは $0.06 \%$ で最高となったが $0.04 〜 0.07 \%$ 間では大きな差はなか ったので有効塩素濃度は $0.05 \%$ とした。

蛍光強度が最大となるときの $\mathrm{pH}$ は Alu, Tau とも 7.0 ～7.5 であるが, 移動相が $0.1 \%$ リン酸であるため,

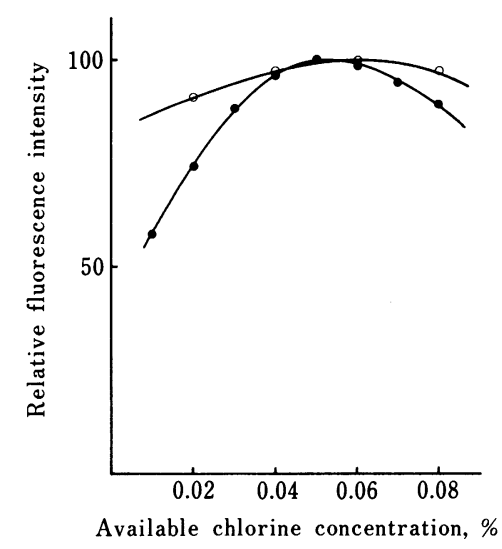

Fig. 1 Effect of available chlorine concentration on fluorescence intensity of at $0.2 \mu \mathrm{g} /$ injection allantoin $(\bigcirc)$ and $0.2 \mu \mathrm{g} /$ injection taurine $(\bigcirc)$

ポストカラム反応系に最初に流人する $\mathrm{NaOCl}$ 試薬の $\mathrm{pH}$ を高める必要がある. $\mathrm{NaOCl}$ 試薬中に添加した水 酸化ナトリウムの量と蛍光強度の関係を検討した結果, Alt, Tauともに $60 \mathrm{mM}$ のときに蛍光強度は最大とな った.

辻らのポストカラム法(5)では Alt の $N$-クロラミンを $\mathrm{I}^{-}$と反応させて検出する際に, 残存する活性塩素を除 去するため, 前もって $\mathrm{NaNO}_{2}$ 溶液を送液しなければな らず, ポストラベル用のポンプ 3 台を必要とし繁雑で あった，本法では $\mathrm{NaNO}_{2}$ と塩酸チアミンは, 同一液中 に混合し送液しても蛍光強度に変化のないことが判明し た。これは過剩の塩素がチアミンと反忍する前に $\mathrm{NaNO}_{2}$ によって分解されることを示している. 従って 送液ポンプ数を減少させることができた。チアミン試薬 中の $\mathrm{NaNO}_{2}$ 濃度と蛍光強度の関係を Fig. 2 に示す.

Alt, Tau とも最高強度の $95 \%$ 程度の蛍光強度があっ た $1 \% \mathrm{NaNO}_{2}$ 溶液を定量条件に採用した. 反忘コイル 槽の温度と蛍光強度の関係を検討した. B コイルを $60^{\circ} \mathrm{C}$ としたと， $\mathrm{A}$ コイル温度を変化 $\left(15^{\circ} \mathrm{C} \sim 70^{\circ} \mathrm{C}\right)$ させても, Tauの蛍光強度はあまり変わらなかった が, 一方 Alt は室温付近で, 最大の蛍光強度を示した.

又, $\mathrm{A}$ コイルを $25^{\circ} \mathrm{C}$ 一定として, 蛍光強度に及ぼす $\mathrm{B}$ コイル温度の影響を検討した. Alt, Tau の蛍光強度は $60^{\circ} \mathrm{C}$ で, 最大となったので $\mathrm{A}$ コイル温度を $25^{\circ} \mathrm{C}, \mathrm{B}$ コイル温度を $60^{\circ} \mathrm{C}$ とした。

\section{$3 \cdot 2$ HPLC 条件の検討}

Alt, Tau は, アミノプロピル化シリカ4), イオン交 


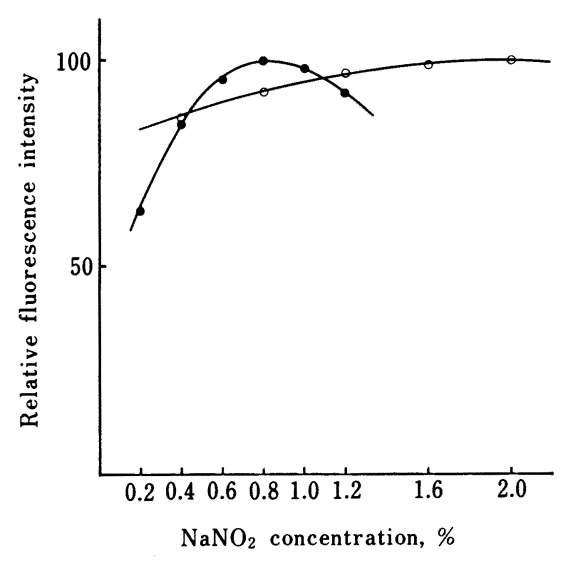

Fig. 2 Effect of sodium nitrite concentration on fluorescence intensity of at $0.2 \mu \mathrm{g} /$ injection allan$\operatorname{toin}(\bigcirc)$ and $0.2 \mu \mathrm{g} /$ injection taurine $(\mathrm{O})$

換 ${ }^{5) 6)}$ ，吸着・分配モード9)での HPLC 分離により， Alt あるいは Tau 単独での缹量が報告されていた。今回, 吸着・分配モードの Ionpac KC-811 (スルホン酸ポリ スチレン系ポーラスポリマー) を，移動相に $0.1 \%$ リン 酸を用いて Alt と Tau を分離した。移動相の $\mathrm{pH}$ が上 昇すると㕯者のピークは接近し, 分離は悪くなり, リン 酸の濃度が $0.1 \%$ 以上では $0.1 \%$ の場合と同様の結果が 与えられたので移動相に $0.1 \%$ リン酸を使用した。な お，溶離液として $0.1 \%$ 過塩素酸を用いても両者は分離 したが，ポストカラム反忍において蛍光強度の変動が見 られたので，これを考慮して $0.1 \%$ リン酸を用いること とした.

\section{$3 \cdot 3$ 再現性及び感度}

従来の Alt, Tau の定量法では内標準物質が使用され ていないが5)9), 使用されていても内標準物質と Tau や

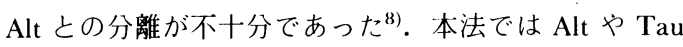
と完全に分離される DMH を内標準物質として設定し た。 その結果, $200 \mathrm{ng} / 20 \mu \mathrm{l}$ injection での相対標準偏差 $(n=6)$ は Alt $0.92 \%$, Tau $0.63 \%$ と定量値の再現性は 良好であった。 又, Alt, Tau とも $20 \mathrm{ng} \sim 2 \mu \mathrm{g} /$ injection の範井で蛍光強度と濃度の間には㨁線関係が存 在した。本ポストカラム蛍光反応システムによる検出限 界は $S / N=2$ において, Alt $4 \mathrm{ng} / 20 \mu \mathrm{l}$ injection, Tau $6 \mathrm{ng} / 20 \mu \mathrm{l}$ injection であった. Alt について, 本法は Kawase らの方法の約 50 倍の感度を有する.

\section{$3 \cdot 4$ 妨害物質の検討}

市販製剤中に, Alt や Tau と共に配合される可能性 のある 28 種の薬物について, その影響を検討した. 結果を Table 1 に示す.これらの薬物は本 HPLC 条件 では, 多くの場合溶出されないか, 溶出されても本ポス トカラムシステムには反応せず, 本法の特異性が確認さ れた. 又, 試料を 50 回繰り返し注入しても, 分離に影 響は見られず, この間, 溶出されない共存物質が分離に 影響しないことが確認された。なお，これ以上連続使用 する場合はカラムの劣化を防ぐため，あらかじめ Shodex Ionpake C-811P $(5 \mathrm{~cm} \times 6.0 \mathrm{~mm})$ をガードカラ ムとして装着することが望ましい。

\section{3 -5 添加回収}

Alt 又は Tau のみを含まない製剂に, 処方量の $50 \% ， 100 \% ， 150 \%$ の標準品を添加して，回収率を測

Table 1 The chromatographic behaviors of various compounds in postcolumn HPLC mehtod

Not eluted compounds

Naphazoline, Phenylephrine, Dibucaine, Lidocaine Pilocarpine, Etilefrine, Diphenhydramine, Neostigmine, Berberine, Methylephedrine, Chlorpheniramine, Glycyrrhizinate, Chondroitin sulfate, Lysozyme, $\varepsilon$-Aminocaproic acid, Aspartic acid, Lysine, Thiamine, Pyridoxine, Nicotinamide, Panthenol, Vitamin U, Caffeine, Carnitine, Chlorhexidine gluconate

Eluted compounds

Azulene sulfonate $(29)^{\text {a) }}[-]^{\text {b) }}$

Riboflavin (26) [-], FAD $(28)[-]$

a) retention time $(\min )$ by UV detector; b) not detected by present postcolumn reaction

Table 2 Results of the determination of allantoin and taurine in pharmaceutical preparations

\begin{tabular}{ccc}
\hline & Found $^{\text {a) }}, \%$ & RSD $^{\text {b) }}, \%$ \\
\hline Eye lotion I & & \\
Allantoin & 98.9 & 2.4 \\
Taurine & 100.7 & 1.6 \\
Eye lotion II & & \\
Allantoin & 98.0 & 0.7 \\
Taurine & 99.1 & 2.1 \\
\hline
\end{tabular}

a) percentage to labeled contents. b) relative standard deviation $(n=5)$. 


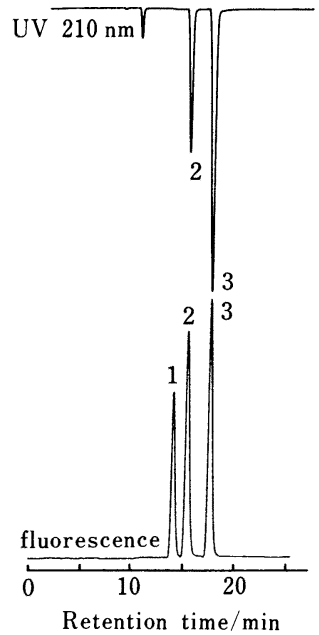

Fig. 3 Chromatograms of eye lotion I obtained by measuring at $210 \mathrm{~nm}$ (top) and by present method (bottom)

The labeled contents of eye lotion I showed in Table 3: 1, taurine; 2, allantoin; 3, IS (5,5-dimethyl hydantoin).

鉒した。その結果，いずれの添加量においても Alt は $99.8 \pm 1.2 \% \quad(n=6)$, Tauは $100.8 \pm 1.4 \% \quad(n=6)$ と良 好な回収率を示した。

\section{3・6 製剤試料中の Alt, Tau の定量}

本法を Alt, Tau を含有する点眼液に適用した測定結
果を Table 2 に, 又, そのクロマトグラムを Fig. 3 に 示した。分析したよ゙の製剤においても良好な結果が得ら れ，クロマトグラムも共存物質の影響のない, 簡単なパ ターンのものが得られた．UV 検出器により同時に記録 したクロマトグラムは, Tau が低波長の UV $210 \mathrm{~nm}$ で も全く検出されず，本法の有用性が示された。本法は点 眼液, 内服液のような液剤については, 内標準浴液での 希釈操作のみで, 分析が问能で, 迅速に前处理なしに製 剤中の Alt, Tauの定量ができる.

\section{文献}

1) R. Borchers: Anal. Biochem., 79, 612 (1977).

2) D. J. Weber, J. W. Higgins: J. Pharm. Sci., 59, $1819(1970)$.

3) 海東常敏, 相楽和彦, 伊東裕一, 中村香能美, 安茂 寿夫: 薬誌, 97, 165 (1977).

4) R. J. Trivedi: J. Assoc. Off. Anal. Chem., 71, 290 (1988).

5) J. Kawase, H. Ueno, A. Nakae, K. Tsuji: J. Chromatogr., 252, 209 (1982).

6) J. Kawase, H. Ueno, A. Nakae, K. Tsuji: J. Chromatogr., 253, 237 (1982).

7) L. L. Hirschberger, J. De La Rosa, M. H. Stipanuk: J. Chromatogr., 343, 303 (1985).

8) P. A. Biondi, A. Negri, A. Ioppolo: J. Chromatogr., 369, 431 (1986).

9) T. Hirai, H. Ohyama, R. Kido: Anal. Biochem., 163, 339 (1987).

10) T. Yokoyama, T. Kinoshita: J. Chromatogr., 518, 141 (1990).

11) T. Yokoyama, T. Kinoshita: J. Chromatogr., in press.

Simultaneous determination of allantoin and taurine in eye lotion by HPLC with postcolumn reaction. Toshio YoкоуамA ${ }^{*}$ and Toshio Kinoshiтa ${ }^{* *}\left({ }^{*}\right.$ Central Research Laboratory, SS Pharmaceutical Co. Ltd., 1143, Nanpeidai, Narita-shi, Chiba 286; ${ }^{* *}$ School of Pharmaceutical Sciences, Kitasato University, 5-9-1, Shirokane, Minato-ku, Tokyo 108)

A method is described for the simultaneous determination of allantoin (Alt) and taurine (Tau) in pharmaceutical preparations by postcolumn HPLC using thiamine reagent on Ionpak ${ }^{\circledR} \mathrm{KC}-811$ column. The effluent from the column was mixed with the hypochlorite reagent and passed through a coil $(3 \mathrm{~m} \times 0.5 \mathrm{~mm}$ PTFE $)$ at ambient temperature to convert Alt and Tau into the corresponding $N$-chloramines. The eluent was then mixed with the thiamine reagent and passed through another coil $(5 \mathrm{~m} \times 0.5 \mathrm{~mm}$ PTFE) at $60^{\circ} \mathrm{C}$ to give highly fluorescent thiochrome. The fluorescence intensity was measured at the wavelengths of Ex. $370 \mathrm{~nm}$ and Em. $420 \mathrm{~nm}$. The hypochlorite reagent was a sodium hypochlorite solution in $0.1 \mathrm{M}$ phosphate buffer $(\mathrm{pH} 7.5$ ) containing $0.05 \%$ available chlorine and $60 \mathrm{mM} \mathrm{NaOH}$. The thiamine reagent was $0.02 \%$ thiamine hydrochloride solution in $0.1 \mathrm{M}$ phosphate buffer $\left(\mathrm{pH} 7.5\right.$ ) containing $1 \% \mathrm{NaNO}_{2}$. A linear relationship was observed between the peak height and amount of Alt or Tau in- 
jected in the range $20 \mathrm{ng} \sim 2 \mu \mathrm{g}$, respectively. The present method was applied to the assay of Tau and Alt in various preparations. The average recovery of spiked Tau and Alt from eye lotions was $100.8 \pm 1.4 \%(n=6)$ and $99.8 \pm 1.2 \%(n=6)$, respectively.

(Received February 26, 1991)

\section{Keyword phrases}

simultaneous determination of allantoin and taurine by HPLC; postcolumn fluorescence reaction with thiamine reagent; pharmaceutical preparations. 